\title{
Expression of Streptococcus mutans Aspartate-Semialdehyde Dehydrogenase Gene Cloned into Plasmid pBR322
}

\author{
By E. K. JAGUSZTYN-KRYNICKA, $†$ M. SMORAWINSKA $†$ AND \\ R. CURTISS III* \\ Institute of Dental Research and Department of Microbiology, University of Alabama in \\ Birmingham, Birmingham, Alabama 35294, U.S.A.
}

(Received 24 March 1981; revised 20 November 1981)

\begin{abstract}
Streptococcus mutans chromosomal DNA cloned into the vector plasmid pBR322 in Escherichia coli is able to complement the metabolic defect of an aspartate-semialdehyde dehydrogenase (EC 1.2.1.11) gene (asd) deletion in the host strain. We constructed two Asd $^{+}$recombinant plasmids, pYA570 and pYA571, containing 4.7 and 4.5 kilobases, respectively, of $S$. mutans chromosomal DNA inserted into the HindIII restriction endonuclease site of pBR322 in the same orientation. The $S$. mutans UAB62 Asd ${ }^{+}$DNA did not hybridize with $E$. coli DNA which contained an intact asd gene, but did hybridize with $S$. mutans UAB62 chromosomal DNA. Derivative $\mathrm{Asd}^{+}$plasmids were then constructed from pYA570. One, pYA574, had a 4.5 kilobase $S$. mutans insert DNA in the opposite direction from pYA570. In another, pYA575, the $S$. mutans insert DNA was reduced in size to 1.3 kilobases. It was seen that the orientation of the $S$. mutans DNA fragment inserted into the promoter region of the pBR322 tetracycline resistance $\left(\mathrm{Tc}^{r}\right)$ gene affected expression of $\mathrm{Tc}^{\mathrm{r}}$. Orientation of the $S$. mutans insert also affected the stability of the plasmid in certain $E$. coli strains. Restriction maps for pYA570, pYA571, pYA574 and pYA575 using the endonucleases EcoRI, BamHI, HindIII, PstI and SalI were determined. Asd ${ }^{+}$plasmiddirected protein synthesis was studied in $E$. coli minicells. The plasmids pYA570, pYA574 and pYA575 each produced large amounts of a protein, with a monomeric molecular weight of about 45000, that was distinct from both pBR322 and E. coli specified proteins: this protein is the $S$. mutans asd gene product. Smaller derivatives of recombinant plasmid pYA575 that were Asd $^{-}$allowed the location of the $S$. mutans asd gene promoter and the direction of transcription to be determined.
\end{abstract}

\section{INTRODUCTION}

The bacterial species Streptococcus mutans includes several genetically and serologically distinct groups (Coykendall, 1974, 1977) and plays a key etiological role in development of dental caries in animals and humans (Gibbons \& vanHoute, 1975; Loesche et al., 1975; Hamada \& Slade, 1980). Genetic analysis of $S$. mutans pathogenicity is, however, limited since classical means of gene transfer such as transformation (Perry \& Kuramitsu, 1981), transduction, and conjugation (LeBlanc et al., 1978) are as yet poorly developed or non-existent. Different approaches have been undertaken to investigate the genetic and biochemical bases of pathogenicity of $S$. mutans, including construction of $S$. mutans plasmid cloning vehicles and transformation into Streptococcus sanguis (Challis) (Behnke \& Ferretti, 1980; Macrina et al., 1980). Work in our laboratory has included cloning of $S$. mutans genes into Escherichia coli K12 using the plasmids pBR322 (Bolivar et al., 1977) and pACYC184

† Present address: Institute of Microbiology, Warsaw University, 00-046 Warsaw, Nowy Swiat 67, Poland. 
(Chang \& Cohen, 1978) and the cosmid pJC74 (Collins, 1979) as cloning vectors, followed by study of $S$. mutans gene organization and expression in the $E$. coli background (Hansen $e t$ al., 1981; Curtiss et al., 1982).

To study the expression of genetic information of the Gram-positive bacterium $S$. mutans, in the Gram-negative bacterium $E$. coli, we chose to clone the gene for an enzyme which is known to be intracellular in both bacteria. Aspartate- $\beta$-semialdehyde dehydrogenase (EC 1.2.1.11) is an enzyme common to the biosynthetic pathways of lysine, methionine and threonine (Umbarger, 1978). In this paper, we report on the cloning of the $S$. mutans asd gene into the HindIII restriction endonuclease site of pBR322, on the construction of $\mathrm{Asd}^{+}$and Asd $^{-}$derivative recombinant plasmids, and on the expression of the $S$. mutans asd gene in $E$. coli $\mathrm{K} 12$ cells.

\section{METHODS}

Bacterial strains and growth media. Bacterial strains used are listed in Table 1. Streptococcus mutans was grown in the complex medium Brain Heart Infusion (Difco) broth at $37^{\circ} \mathrm{C}$ without aeration. Liquid minimal media (ML; Curtiss, 1965) for growth of $E$. coli strains contained $0.5 \%(\mathrm{w} / \mathrm{v})$ glucose and the following supplements per $\mathrm{ml}$ as needed: $50 \mu \mathrm{g} \mathrm{L}$-meso-diaminopimelic acid (DAP), $22 \mu \mathrm{g} \mathrm{L}$-histidine, $20 \mu \mathrm{g}$ L-isoleucine, $40 \mu \mathrm{g}$ DL-valine, $88 \mu \mathrm{g}$ L-lysine, $0.5 \mu \mathrm{g}$ biotin. Minimal agar (MA) contained $1.5 \%(\mathrm{w} / \mathrm{v})$ agar. To grow $E$. coli $\chi 1849$ and $E$. coli $\chi 2656$ for minicell harvest, $0.5 \%$ (w/v) Casamino acids (Difco) replaced individual amino acids. Complex media for $E$. coli growth were L-broth (Lennox, 1955) and Penassay agar medium (PA, Difco), both supplemented with DAP when necessary. Antibiotic concentrations used for routine selection were (per ml): $25 \mu \mathrm{g}$ ampicillin (Ap, Lederle) and $25 \mu \mathrm{g}$ tetracycline (Tc, Lederle). To amplify plasmid DNA, cultures in the late-exponential phase were incubated for $16 \mathrm{~h}$ at $37^{\circ} \mathrm{C}$ in the presence of chloramphenicol $(\mathrm{Cm}$, Sigma) $\left(170 \mu \mathrm{g} \mathrm{ml}^{-1}\right)$.

Tetracycline resistance level. PA plates were inoculated with 100-300 cells (in exponential growth phase), incubated overnight and replica plated on to PA plates with $0,1,10,25,75,100,150 \mathrm{or} 200 \mu \mathrm{g}$ tetracycline $\mathrm{ml}^{-1}$.

Preparation of DNA. For plasmid isolation after amplification, one-litre bacterial cultures were lysed by the method of Guerry et al. (1973) modified by the addition of a freeze-thaw step after lysozyme digestion, to facilitate lysis. Plasmid DNA was purified from cleared lysates by two $\mathrm{CsCl}$-ethidium bromide equilibrium density gradient centrifugations (Hansen et al., 1981). After removal of ethidium bromide by isopropanol extraction, plasmid DNA was dialysed against $10 \mathrm{~mm}$-Tris. $\mathrm{HCl} / 1 \mathrm{mM}$-EDTA $(\mathrm{pH} 8.0)$ at $4{ }^{\circ} \mathrm{C}$. When necessary, plasmid DNA was concentrated by precipitation with 2 vol. ethanol and 0.1 vol. $2 \mathrm{M}$-sodium acetate $\left(\mathrm{pH} \mathrm{5.3)}\right.$ at $-20^{\circ} \mathrm{C}$.

To obtain small amounts of DNA from $1 \mathrm{ml}$ overnight cultures to screen for plasmid restriction endonuclease digestion patterns, two rapid cleared lysate techniques were used. One was the rapid alkaline extraction procedure of Birnboim \& Doly (1979), and the second was a scaled-down protocol by J. P. Robeson (personal communication) of the Triton X-100 cleared lysis technique of Katz et al. (1973).

To prepare chromosomal DNA from $S$. mutans, cells from one-litre overnight cultures were pelleted, washed with $2 \mathrm{M}-\mathrm{NaCl}$ and suspended in a solution of $20 \%$ glucose in $25 \mathrm{~mm}$-sodium phosphate buffer (pH 6.4). Bacterial cells were lysed by adding mutanolysin (kindly provided by Kanae Yokogawa, Dainippon Pharmaceutical Co., Osaka, Japan) to a concentration of $1 \mathrm{mg} \mathrm{ml}^{-1}$ and incubating for $10 \mathrm{~min}$ at $60^{\circ} \mathrm{C}$ (Yokogawa et al., 1974). To complete lysis, Sarkosyl (Sigma) was added to a final concentration of $0.5 \%(\mathrm{w} / \mathrm{v})$. The whole cell lysate was mixed with $\mathrm{CsCl}$ to a density of $1.7 \mathrm{~g} \mathrm{ml}^{-1}$ and centrifuged to equilibrium in a Beckman Ti50 rotor at $37000 \mathrm{rev}$. $\min ^{-1}$ for $48 \mathrm{~h}$, at $15^{\circ} \mathrm{C}$. Collected chromosomal DNA was dialysed against $10 \mathrm{~mm}$-Tris/10 mM-EDTA buffer (pH 8.0), treated with Proteinase $\mathrm{K}$ (Merck) $\left(1 \mathrm{mg} \mathrm{ml}^{-1}\right)$ for $3 \mathrm{~h}$ at $37^{\circ} \mathrm{C}$ and then recentrifuged on another $\mathrm{CsCl}$ gradient.

Enzymes. The restriction endonucleases EcoRI, SalI, PstI, HindIII and BamHI were purchased from New England Biolabs. T4 polynucleotide ligase was the kind gift of C.K.K. Nair; we also used commercial T4 polynucleotide ligase (New England Biolabs) and E. coli DNA polymerase I (Boehringer-Mannheim). Conditions for digestion of DNA by restriction endonucleases were as described in the New England Biolabs catalogue. After digestion, DNA was heated for $10 \mathrm{~min}$ at $65^{\circ} \mathrm{C}$ to inactivate restriction enzymes.

Formation of recombinant plasmid molecules. pBR322 plasmid DNA and S. mutans chromosomal DNA, digested separately with HindIII restriction endonuclease, were mixed at a ratio of $1 \mu \mathrm{g}$ pBR322 to $3 \mu \mathrm{g} S$. mutans DNA. DNA ligase reactions were carried out in a $100 \mu \mathrm{l}$ mixture containing $50 \mathrm{mM}$ - Tris. $\mathrm{HCl}$ (pH 7.6), $10 \mathrm{mM}-\mathrm{MgCl}_{2}, 20 \mathrm{~mm}$-dithiothreitol and $1 \mathrm{mM}-\mathrm{ATP}$ : reaction mixtures containing $2.5 \mu \mathrm{g}$ plasmid and $7.5 \mu \mathrm{g}$ chromosomal DNA were incubated overnight at $12{ }^{\circ} \mathrm{C}$ with 0.3 units of $\mathrm{T} 4$ polynucleotide ligase; then the mixture was incubated at $65^{\circ} \mathrm{C}$ for $5 \mathrm{~min}$.

When recombinant plasmid DNA was restriction endonuclease digested and religated, we incubated $0.5-1 \mu \mathrm{g}$ DNA at $12^{\circ} \mathrm{C}$ for $16 \mathrm{~h}$ in a $50 \mu \mathrm{l}$ reaction mixture with 0.1 units T4 polynucleotide ligase. 
Table 1. Bacterial strains

Strain

Escherichia coli $\mathrm{K} 12$

$\chi 289$

$\chi 1825$

$\chi 1849$

$\chi 2656$

V517

Streptococcus mutans

UAB62
Description*

\author{
$\lambda-$ tte- 1 \\ supE42 tte-1 $\Delta 29[$ bioH-asd $] \lambda^{-}$ \\ tonA53 dapD8 minA1 purE41 supE42 $\Delta 40[\mathrm{gal}-\mathrm{uvrB}] \lambda^{-}$ \\ minB2 his-53 nalA25 metC65 tte-1 $\triangle 29[$ bioH-asd] ilv-277 \\ cycB2 cycAl oms-1 hsdR2 \\ $\chi 1849$ that contains the pBR322 plasmid; $\mathrm{Ap}^{\mathrm{r}} \mathrm{Tc}^{\mathrm{r}}$ \\ Contains multiple plasmids for size standards
}

Serotype $c, \operatorname{Str}^{r} \operatorname{Rif}^{r} \mathrm{Mel}^{+} \mathrm{Raf}^{+}$
Reference/source

This laboratory

This laboratory

This laboratory

Bolivar et al. (1977)

Macrina et al. (1978)

Derived from PS14 Str $^{r}$

* The symbols for $E$. coli strains used are those described by Bachmann \& Low (1980). Plasmid pBR322 confers resistance to ampicillin $\left(\mathrm{Ap}^{\mathrm{r}}\right)$ and tetracycline $\left(\mathrm{Tc}^{\mathrm{r}}\right)$. The $S$. mutans phenotypes are resistance to streptomycin $\left(\mathrm{Str}^{r}\right)$ and rifampicin $\left(\mathrm{Rif}^{\mathrm{r}}\right)$, or ability to ferment melibiose $\left(\mathrm{Mel}^{+}\right)$and raffinose $\left(\mathrm{Raf}^{+}\right)$.

Transformation. Ligated DNA, diluted to a concentration of $20-100 \mathrm{ng} \mathrm{ml}^{-1}$ in $67 \mathrm{~mm}-\mathrm{CaCl}_{2} / 10 \mathrm{~mm}-\mathrm{Tris}$ (pH 8.0) and put on ice for at least $10 \mathrm{~min}$, was used to transform $E$. coli $\mathrm{K} 12$ strain $\chi 1849$ by a method developed specifically for $\chi 1849$ by M. Inoue, L. Alexander and R. Curtiss III (unpublished data). In this procedure, all sedimentation is gentle $\left(7710 \mathrm{~g}\right.$ for $10 \mathrm{~min}$ at $20^{\circ} \mathrm{C}$ ) and all resuspension is without vortexing. An $18 \mathrm{~h}, 37^{\circ} \mathrm{C}$ culture of $\chi 1849$ in $5 \mathrm{ml}$ L-broth plus DAP was diluted $1: 10$ into $20 \mathrm{ml} \mathrm{L}$-broth plus DAP and incubated for about $3 \mathrm{~h}$ with shaking at $37^{\circ} \mathrm{C}$, to an absorbance of 0.4 at $600 \mathrm{~nm}$. Cells were sedimented and resuspended in $10 \mathrm{ml}$ $25 \mathrm{mM}-\mathrm{KCl} / 10 \mathrm{mM}$-Tris. $\mathrm{HCl}$ buffer ( $\mathrm{pH} \mathrm{8.0}$ ). After $5 \mathrm{~min}$ at $20^{\circ} \mathrm{C}$, cells were sedimented and resuspended into $10 \mathrm{ml} 100 \mathrm{mM}-\mathrm{CaCl}_{2} / 10 \mathrm{mM}$-Tris. $\mathrm{HCl}$ buffer $\left(\mathrm{pH} \mathrm{8.0}\right.$ ), and held at $20^{\circ} \mathrm{C}$ for $20 \mathrm{~min}$. Cells were then sedimented and resuspended in $10 \mathrm{ml} 67 \mathrm{mM}-\mathrm{CaCl}_{2} / 10 \mathrm{~mm}$-Tris. $\mathrm{HCl}(\mathrm{pH} \mathrm{8.0)}: 0.5 \mathrm{ml}$ of these cells were put into a clean 13 $\times 100 \mathrm{~mm}$ Pyrex tube on ice for at least $2 \mathrm{~min}$. Using a chilled pipette, $200 \mu$ l chilled cells were mixed with $100 \mu \mathrm{l}$ chilled DNA and incubated at $4{ }^{\circ} \mathrm{C}$ for $20 \mathrm{~min}$. The transformation mixture was then heat shocked at $42{ }^{\circ} \mathrm{C}$ for $2 \mathrm{~min}$, and held at $20^{\circ} \mathrm{C}$ for $10 \mathrm{~min}$. To allow phenotypic expression, $0.9 \mathrm{ml} \mathrm{L}$-broth plus DAP was added, followed by incubation at $37^{\circ} \mathrm{C}$ for $90 \mathrm{~min}$. Samples $(0.1 \mathrm{ml})$ were spread on to freshly made plates of PA plus DAP and antibiotic. The use of overly dry plates or the practice of spreading to dryness were both avoided since either reduced transformant yield 100- to 1000-fold.

Gel electrophoresis and DNA size determinations. DNA was electrophoresed in various types of slab gels: $1.2 \%, 1 \%$ or $0.8 \%(\mathrm{w} / \mathrm{v})$ agarose (Sigma), agarose acrylamide $(0.7 \%$ and $2 \%, \mathrm{w} / \mathrm{v})$ or $5 \%(\mathrm{w} / \mathrm{v})$ acrylamide. Running buffer was $40 \mathrm{~mm}$-Tris, $5 \mathrm{~mm}$-sodium acetate and $1 \mathrm{~mm}$-EDTA adjusted to $\mathrm{pH} 7.6$ with acetic acid (Hayward \& Smith, 1972). After ethidium bromide staining, the gels were photographed using u.v. light, Polaroid T57 film and a red filter. Molecular weight standards for supercoiled plasmid DNA were pBR322 (Sutcliffe, 1978) and the plasmids from strain V517 (Table 1). Molecular weight standards for linear restriction endonuclease fragments of DNA were chosen to bracket the sizes of the unknown fragments: we used variously bacteriophage $\lambda$ DNA digested with EcoRI or HindIII and double-stranded $\phi$ X174 DNA digested with HaeIII. Standard curves were drawn as plots of molecular weight versus relative mobility (supercoiled DNAs were plotted on double-logarithm and linear DNAs on semi-logarithm paper). Plasmid sizes were measured both as intact molecules and as the summation of linear fragments. For mapping of restriction endonuclease sites, various double digestions were performed.

Southern blot hybridization. Chromosomal or plasmid DNA electrophoresed through $0.8 \%$ agarose gels was transferred to nitrocellulose filters and hybridized with radioactive probe DNA as described by Southern (1975). Probe plasmid DNA was labelled with $\left[\alpha^{-32}\right.$ P]dATP (New England Nuclear) by the nick translation method of Rigby et al. (1977). Hybrids were visualized by autoradiography.

Minicell protein analysis. Minicells of $E$. coli $\chi 1849$ or plasmid-containing $\chi 1849$ derivatives were isolated by standard methods (Frazer \& Curtiss, 1975): minicells from $50 \mathrm{ml}$ of a late-exponential phase culture were purified by one differential centrifugation and two velocity centrifugations in discontinuous sucrose gradients. Minicells were incubated for $20 \mathrm{~min}$ at $37^{\circ} \mathrm{C}$ in $0.6 \mathrm{ml} \mathrm{ML}$ without DAP and then labelled by the addition of $2 \mu \mathrm{Ci}$ ${ }^{14} \mathrm{C}$-labelled amino acid mixture [New England Nuclear, $0.1 \mathrm{mCi} \mathrm{ml}^{-1}\left(3.7 \mathrm{MBq} \mathrm{ml}^{-1}\right)$ ] followed by incubation for 20 min. Labelled minicells were pelleted, washed once with cold buffered saline with gelatin (Curtiss, 1965), suspended in $50 \mu \mathrm{l}$ sample buffer [ $3 \%$ sodium dodecyl sulphate (SDS), $5 \% \beta$-mercaptoethanol, $10 \%$ glycerol, $0.1 \%$ bromophenol blue, $62.5 \mathrm{mM}$-Tris. $\mathrm{HCl}, \mathrm{pH} 6.81$ and heated at $100^{\circ} \mathrm{C}$ for $5 \mathrm{~min}$. Proteins from disrupted minicells were fractionated on SDS-polyacrylamide gels (6\% stacking gel, $10 \%$ separating gel) by the method of Laemmli \& Favre (1973). After fixing, the gels were stained with $0.01 \%$ Coomassie Blue in $50 \%$ methanol and $9 \%$ acetic acid, destained with $7 \%$ acetic acid in $5 \%$ methanol, impregnated with a scintillator (Enhance, New England Nuclear), dried and fluorographed. Protein molecular weight standards employed were from BioRad. 
Cloning of the S. mutans aspartate semialdehyde dehydrogenase gene into pBR322. S. mutans UAB62 genes were 'shotgun' cloned into the single HindIII endonuclease restriction site of the ampicillin and tetracycline antibiotic resistance $\left(\mathrm{Ap}^{\mathrm{r}} \mathrm{Tc}^{\mathrm{r}}\right)$ plasmid, pBR322. Insertion of DNA at this site often prevents the expression of $\mathrm{Tc}^{\mathrm{r}}$ (Bolivar et al., 1977). The frequency of transformation into $E$. coli $\chi 1849$ cells with ligated DNA was $1 \times 10^{6} \mathrm{Ap}^{\mathrm{r}}$ transformants per $\mu \mathrm{g}$ pBR322 DNA. Two of approximately $30000 \mathrm{Ap}^{\mathrm{r}}$ transformants, selected on PA agar with ampicillin, were also $\mathrm{Asd}^{+}$, as evidenced by their ability to grow on minimal agar with ampicillin but lacking threonine. These two $\mathrm{Asd}^{+} \mathrm{Ap}^{\mathrm{r}}$ clones were also $\mathrm{Tc}^{\mathrm{s}}$. The recombinant plasmids from the two $\mathrm{Asd}^{+}$clones designated pYA570 and pYA571, were both larger than pBR322, and had DNA inserts at the HindIII site of sizes 4.7 and 4.5 kilobases $(\mathrm{kb})$, respectively.

Genetic complementation of the asd mutation in $E$. coli $\chi 1825$. In $E$. coli strain $\chi 1825$, unlike $\chi 1849$, only a single mutation, the $\Delta 29[$ bioH-asd $]$ deletion, affects the diaminopimelic acid (DAP), methionine and threonine biosynthetic pathways. Growth of $\chi 1825$ on minimal agar requires DAP, methionine and threonine. When $\chi 1825$ was transformed by pYA570 plasmid DNA with selection for growth in the absence of threonine, methionine and DAP, either singly or in combinations, transformants were obtained at similar frequencies in each case. These frequencies were the same as the frequency of $\mathrm{Ap}^{r}$ transformants selected on PA plates with DAP.

A generation time of $1.5 \mathrm{~h}$ was obtained for both $\chi 1825$ and $\chi 1825$ (pYA570) cells on minimal medium supplemented with glucose, biotin, DAP, methionine, and threonine, as well as for $\chi 1825$ (pYA570) cells on minimal medium supplemented only with glucose and biotin. These results suggested that $S$. mutans DNA cloned into the HindIII cleavage site of pBR322 provided a function which substituted for the deleted asd gene in E. coli $\chi 1825$.

Hybridization of pYA570 insert DNA with S. mutans UAB62 DNA. The following Southern filter blot hybridization experiment revealed that the specific nucleotide sequence which encodes aspartate- $\beta$-semialdehyde dehydrogenase in $S$. mutans UAB62 was unrelated to the $E$. coli asd gene sequence and only encoded for similar function. HindIII-digested, ${ }^{32}$ P-labelled probe pYA570 DNA hybridized with HindIII-digested pYA570 DNA and $S$. mutans UAB62 chromosomal DNA, but not with $E$. coli $\chi 1825$ or $\chi 289$ chromosomal DNAs $(\chi 289$ has an intact asd gene). This indicated that the inserted fragment is a part of the $S$. mutans UAB62 genome (Fig. 1). In a control experiment, radioactive HindIII-digested pBR322 plasmid DNA did not hybridize with either $E$. coli or $S$. mutans chromosomal DNA (data not shown); thus the hybridization seen for pYA570 was all due to the inserted $4.7 \mathrm{~kb}$ S. mutans DNA.

Characterization of $A s d^{+}$recombinant plasmid DNA. The relative locations of PstI, EcoRI, $B a m \mathrm{HI}$ and HindIII endonuclease cleavage sites have been mapped (see Methods). The $S$. mutans DNA in both recombinant plasmids is inserted into the HindIII restriction site in the same orientation relative to pBR322, and pYA570 differs from pYA571 by having an extra $0.2 \mathrm{~kb}$ HindIII fragment (Fig. 2). Neither insert DNA is cut by SalI endonuclease.

To determine whether the $S$. mutans DNA responsible for the Asd ${ }^{+}$phenotype is expressed in $E$. coli cells in both orientations in pBR322, pYA570 DNA was digested with HindIII, ligated and transformed into $E$. coli $\chi 1825$ cells with selection for $\mathrm{Ap}^{\mathrm{r}} \mathrm{Asd}^{+}$transformants. Half of fifty transformant colonies screened were found to be $T c^{r}$. Plasmids from four $\mathrm{Ap}^{r} \mathrm{Tc}^{r} \mathrm{Asd}^{+}$clones and from four $\mathrm{Ap}^{r} \mathrm{Tc}^{\mathrm{s}} \mathrm{Asd}^{+}$clones all had molecular sizes of about $9 \mathrm{~kb}$, similar to the original pYA570 plasmid. Restriction endonuclease analysis with EcoRI or PstI of purified plasmid DNA from one $\mathrm{Ap}^{r} \mathrm{Tc}^{r} \mathrm{Asd}^{+}$clone, designated as pYA574, revealed that the $S$. mutans DNA was inserted into pBR322 in the opposite orientation from pYA570 (Fig. 2). The fact that $S$. mutans DNA cloned in both orientations gave an $\mathrm{Asd}^{+}$phenotype 


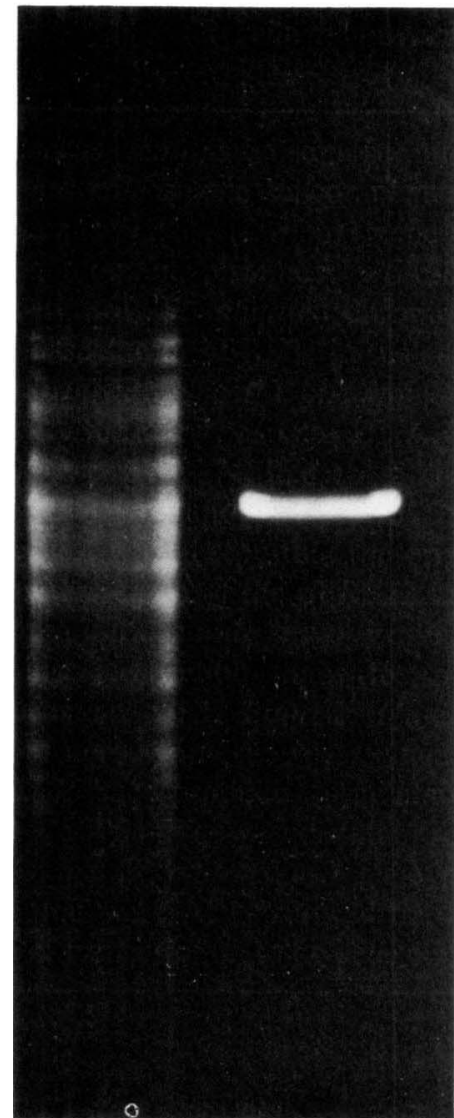

(a)

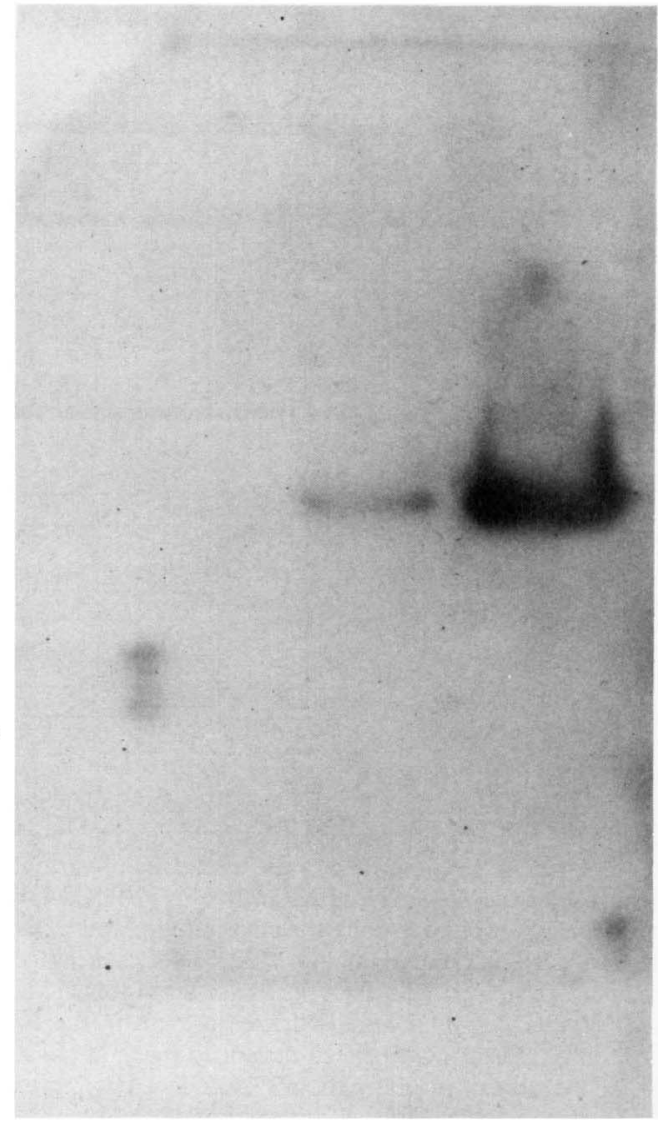

(b)

Fig. 1. Hybridization of pYA570 plasmid DNA with $S$. mutans UAB62, E. coli $\chi 289$ and E. coli $\chi 1825$ chromosomal DNA. Unlabelled chromosomal and plasmid DNAs were digested with HindIII restriction endonuclease, electrophoresed through $0.8 \%$ agarose, denatured and transferred to nitrocellulose paper. Probe DNA was pYA570 digested with HindIII and labelled with [ $\alpha-{ }^{32}$ P]dATP by nick translation. Hybridization was detected by autoradiography. (a) Photograph of HindIII-digested $S$. mutans UAB62 chromosomal DNA (lane 1) and plasmid pYA570 DNA (lane 2) in the agarose gel before transfer (there is only one apparent band since pBR322 and the insert are nearly the same size). (b) Autoradiograph of pYA570, E. coli and $S$. mutans DNA after hybridization with ${ }^{32}$-labelled pYA570 DNA. Unlabelled DNA was as follows: lane 1, $\chi 289$; lane 2, $\chi 1825$; lane 3, UAB62, lane 4, pYA570.

suggested that a functional $S$. mutans promoter for the $S$. mutans asd gene was recognized by $E$. coli RNA polymerase. Furthermore, in one orientation (pYA574) the $S$. mutans DNA fragment provided a promoter function which substituted for the disrupted promoter of the pBR322 $\mathrm{Tc}^{\mathrm{r}}$ gene(s). Unlike other $\mathrm{Asd}^{+}$plasmids we have constructed (above and below), pYA574 was unstable under non-selective growth conditions in $\chi 1849$, but not in $\chi 1825$ (data not shown). The reason for this strain-specific, orientation-dependent instability is unclear.

Construction of a low molecular weight Asd ${ }^{+}$derivative of $p Y A 570$. To determine the minimum size of $S$. mutans DNA required for expression of the $\mathrm{Asd}^{+}$phenotype, we next attempted to reduce the size of $S$. mutans DNA cloned into pBR322. When we subcloned the $2.8 \mathrm{~kb}$ pYA570 BamHI fragment into the BamHI cleavage site of pBR322, all $\mathrm{Ap}^{\mathrm{r}} \mathrm{Tc}^{\mathrm{s}}$ 


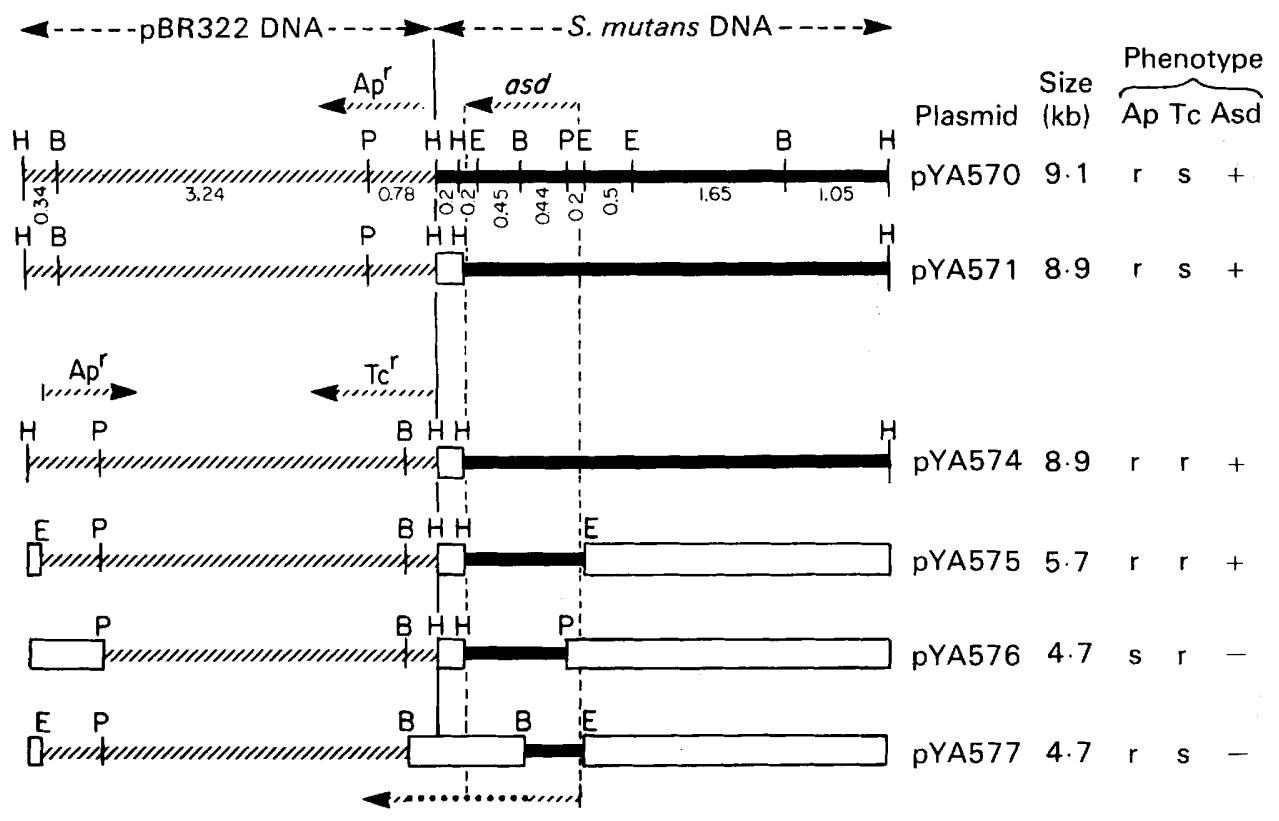

Fig. 2. Physical map of $\mathrm{Asd}^{+}$and $\mathrm{Asd}^{-}$recombinant plasmids showing cleavage sites for EcoRI (E), HindIII (H), PstI (P) and BamHI (B) restriction endonucleases. The construction and characterization of these plasmids was described in the text; sizes of various deletions are indicated by open boxes. Note that the size of the EcoRI-HindIII deletion in pBR322 DNA, only 29 base pairs, has been exaggerated on this map for visibility. Each plasmid is represented as a linear map, with the ends being a HindIII restriction site. Note that the pBR322 DNA is inserted in opposite orientation for the lower four plasmids as compared with the upper two. Distances in kilobases $(\mathrm{kb})$ are shown for pYA570. All of the EcoRI, HindIII, BamHI and PstI sites present in the S. mutans insert are marked on pYA570; for clarity, only the restriction sites relevant to plasmid construction are indicated in the $S$. mutans insert DNA of the other five plasmids. pBR322 DNA is represented by a broken thick line and $S$. mutans DNA by a solid thick line. A thinner broken line with an arrow represents transcription regions for ampicillin and tetracycline resistances $\left(\mathrm{Ap}^{r}, \mathrm{Tc}^{r}\right)$ in $\mathrm{pBR} 322$ and for aspartate- $\beta$-semialdehyde dehydrogenase (asd) in $S$. mutans DNA. The bottom asd transcription arrow represents a hypothetical fused protein (see Fig. 3).

transformants isolated had an $\mathrm{Asd}^{-}$phenotype. Examination of 10 of these bacterial clones revealed that all contained a recombinant plasmid with an insert of about $2.8 \mathrm{~kb}$, as was expected. It was concluded that one of the BamHI cleavage sites was most probably located inside the asd structural gene or promoter. This conclusion is also compatible with our inability to construct $\mathrm{Asd}^{+}$recombinant plasmids in a BamHI 'shotgun' cloning of S. mutans chromosomal DNA.

When we subcloned portions of the $S$. mutans insert DNA, made by digesting pYA570 completely with $H$ indIII and incompletely with $E c o$ RI, into pBR322 plasmid DNA which was completely digested with HindIII and EcoRI, we obtained three transformant bacterial clones that were $\mathrm{Ap}^{\mathrm{r}} \mathrm{Tc}^{r} \mathrm{Asd}^{+}$and carried plasmid DNA of the same reduced size, in comparison with pYA571. Plasmid DNA from one of these clones, designated pYA575, was isolated, purified and mapped as described in Methods. The pYA575 recombinant plasmid had a molecular size of $5.7 \mathrm{~kb}$, having lost the $2.7,0.5$ and $0.2 \mathrm{~kb}$ DNA fragments of pYA570 generated by HindIII and EcoRI digestion. Thus no more than about $1.3 \mathrm{~kb}$ of $S$. mutans DNA was required to code for the Asd ${ }^{+}$function necessary to substitute for the deleted asd gene in E. coli $\chi 1825$ (Fig. 2).

The expression of $\mathrm{Tc}^{r}$ by pYA575 might be due to transcription initiation at a promoter sequence on the $S$. mutans inserted DNA. However, the resistances to tetracycline of $\chi 2656$, which contains pBR322, and $\chi 1849$ (pYA575), determined as a $50 \%$ inhibition of growth on 
plates, were both the same: between 100 and $150 \mu \mathrm{g}$ tetracycline $\mathrm{ml}^{-1}$. The $\chi 1849$ plasmid-free control and $\chi 1849$ (pYA570) both showed a tetracycline minimal inhibitory concentration of about $1 \mu \mathrm{g} \mathrm{ml}^{-1}$.

Inactivation of the cloned asd gene. We next constructed two Asd ${ }^{-}$derivatives of pYA575. One type was obtained by Pst I digestion of pYA575 followed by religation and selection for $\mathrm{Tc}^{\mathrm{r}}$ transformants in $\chi 1849$. These $\mathrm{Tc}^{\mathrm{r}}$ transformants were $\mathrm{Ap}^{\mathrm{s}} \mathrm{Asd}^{-}$. Plasmid DNA from several clones examined all had a molecular size of about $4.7 \mathrm{~kb}$, and only one Pst I endonuclease site. One representative plasmid was designated pYA576 (Fig. 2). Asd ${ }^{-}$ derivatives of pYA575 of the second type were constructed by HindIII and BamHI digestion of pYA575 followed by religation. Plasmid DNA from five $\mathrm{Ap}^{\mathrm{r}} \mathrm{Tc}^{\mathrm{s}} \mathrm{Asd}$ - transformants examined had a molecular size of about $4.7 \mathrm{~kb}$. One of these plasmids was designated pYA577. pYA577 DNA had no cleavage sites for the HindIII restriction enzyme and had only one BamHI endonuclease site. Restriction maps of both deletion plasmids are given in Fig. 2.

Identification of protein encoded by Asd ${ }^{+}$recombinant plasmids. A comparison of protein synthesis in minicells that contained only the vector plasmid pBR322 with those that contained pYA570, pYA574 or pYA575 DNA allowed us to determine the specific polypeptide(s) associated with cloned $S$. mutans DNA: an autoradiograph of radioactively labelled minicell proteins after SDS-polyacrylamide gel electrophoresis is shown in Fig. 3. First, several protein bands were present in plasmid-free minicells: they were due to stable mRNA (Levy, 1975) (Fig. 3, lane 1). The cloning vector pBR322 specified the synthesis of several proteins (Fig. 3, lane 2). The most prominent bands corresponded to three $\beta$-lactamase proteins in the range 25000-31000 daltons. The $\beta$-lactamase gene promoter initiates transcription more efficiently than the $\mathrm{Tc}^{r}$ gene promoters (Stüber \& Bujard, 1981), so that the pBR322-directed minicell-protein profile is dominated by the $\beta$-lactamase proteins (Sutcliffe, 1978). But the 34000 dalton protein involved in Tc resistance, which disappears when pBR322 plasmid DNA has foreign DNA inserted in the BamHI or Sall restriction site (Tait \& Boyer, 1978), was also visible (Fig. 3, lane 2). This protein migrates only slightly faster than one of the stable mRNA proteins.

The $\mathrm{Asd}^{+}$recombinant plasmids specified a novel polypeptide of monomeric molecular weight of about 45000 (Fig. 3, lanes $5,6,7$ ) which must be encoded by the $1.3 \mathrm{~kb} S$. mutans DNA common to all (Fig. 2). This unique band was also visible after SDS-polyacrylamide gel electrophoresis and Coomassie blue staining of proteins isolated from unlabelled E. coli $\chi 1849$ cells carrying pYA570 (Curtiss et al., 1982). Notably, Asd ${ }^{+}$recombinant plasmids gave rather faint bands for $\beta$-lactamase when compared with pBR322 itself (Fig. 3). This observation suggested that the $S$. mutans asd promoter is strong and may compete with the $A p^{r}$ and $\mathrm{Tc}^{r}$ gene promoters for the limiting amounts of RNA polymerase in minicells (Frazer \& Curtiss, 1975). Stüber \& Bujard (1981) also observed that cloned foreign DNA carrying an efficient promoter can compete with promoters of pBR322.

A comparison of polypeptide synthesis in minicells directed by the Asd- plasmids pYA576 and pYA577 (Fig. 3) allowed us to determine the location of the $S$. mutans asd gene promoter and direction of asd gene transcription shown in Fig. 2. In both of these cases, deletion of $S$. mutans DNA correlated with disappearance of the 45000 molecular weight polypeptide. pYA576 specified only moderate synthesis of the 34000 dalton, pBR322-encoded tetracycline resistance protein (this protein appears just slightly below the lower stable mRNA protein: compare with plasmid-free control). $\beta$-Lactamase proteins were not made by this $\mathrm{Ap}^{\mathrm{s}}$ plasmid (Fig. 3, lane 3). These results with pYA576 suggested that the asd promoter was located on the $0.20 \mathrm{~kb}$ EcoRI-PstI fragment of pYA575. When we analysed protein synthesis directed by pYA577, we found that pYA577 produced a novel, probably fused, protein of smaller monomeric molecular weight (32000) in addition to the $\beta$-lactamase proteins expected (Fig. 3, lane 4). We assume that this protein is a fused product since it is larger than coding capacity 


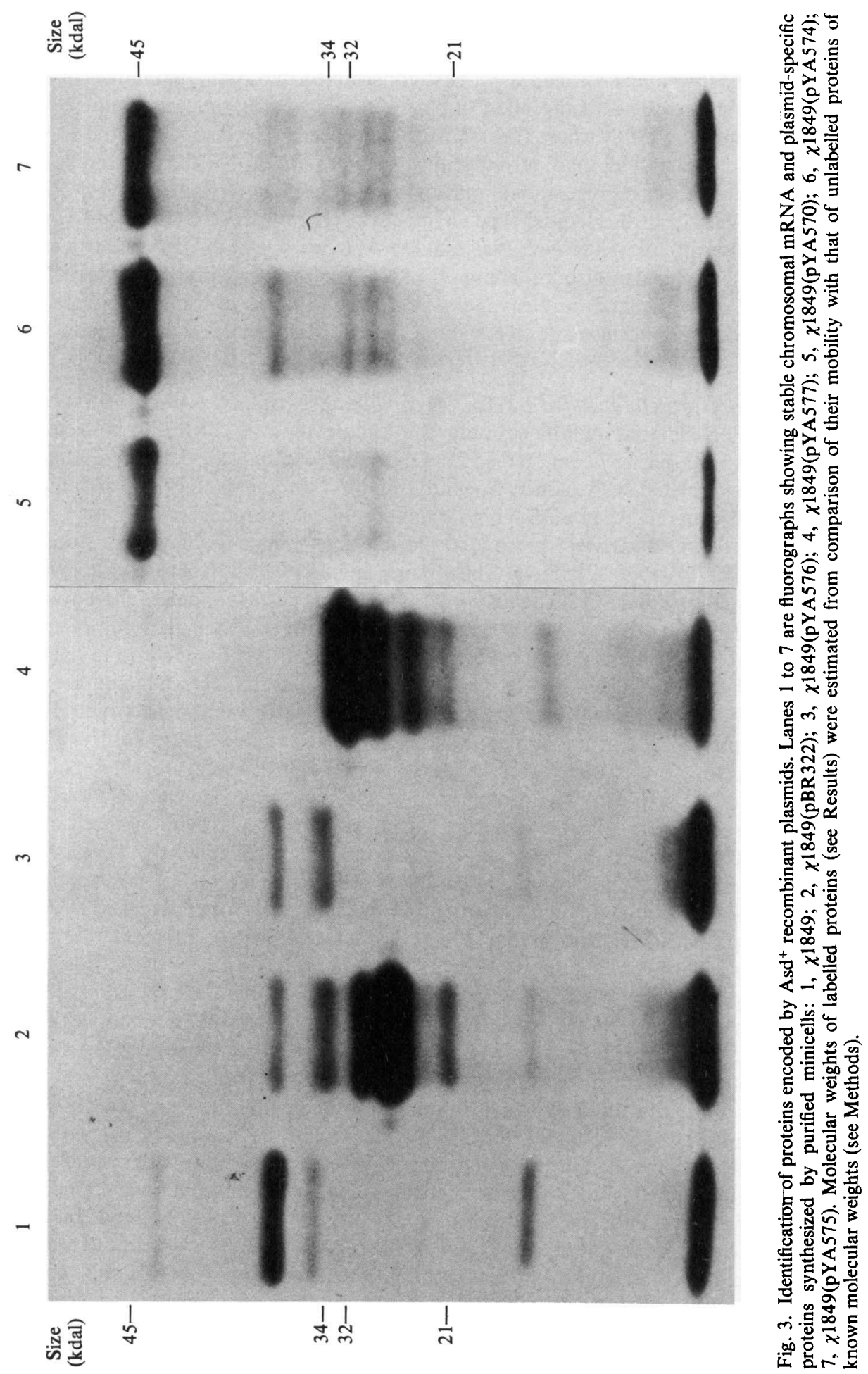


of the $S$. mutans insert in pYA577. The proposed location of the $S$. mutans asd gene promoter and direction of transcription are shown on Fig. 2. The coding capacity of the $S$. mutans DNA insert in pYA575 (about 430 amino acids), the molecular size of the asd gene product (about 400 amino acid moieties) and the fact that the pYA576 plasmid does not specify synthesis of truncated or fused protein, all strongly support the hypothesis that the asd gene promoter is located in the $0.2 \mathrm{~kb}$ EcoRI-PstI $S$. mutans DNA fragment adjacent to the EcoRI restriction site and that direction of transcription of asd is towards the HindIII recognition site.

\section{DISCUSSION}

We have shown that chromosomal genetic information (the asd gene) from $S$. mutans, a Gram-positive bacterium, can be stably maintained (depending on the host strain) in the pBR322 vector plasmid in either of the two possible orientations and can complement an $E$. coli $\mathrm{K} 12$ asd deletion mutation. Our smallest $\mathrm{Asd}^{+}$chimeric plasmid contained only about 100 base pairs of DNA more than is necessary to encode the approximately 45000 molecular weight polypeptide which we believe to be the asd protein. Aspartate- $\beta$-semialdehyde dehydrogenase has been characterized after purification from $E$. coli cells and commercial baker's yeast: the molecular weight of the $E$. coli enzyme is approximately 70000 (Hegeman et al., 1970), while yeast aspartate- $\beta$-semialdehyde dehydrogenase has a molecular weight of 156000 and consists of four identical subunits of molecular weight $41000 \pm 4000$ (Holland $\&$ Westhead, 1973). We do not know whether the $S$. mutans aspartate- $\beta$-semialdehyde dehydrogenase holoenzyme is multimeric.

In protein synthesis experiments the asd protein surprisingly appeared in great excess compared with products of the pBR322 ampicillin or tetracycline resistance genes. No other $S$. mutans gene cloned in $E$. coli in this laboratory has had as high a level of expression as the asd gene. Examination of the $S$. mutans asd promoter by RNA polymerase binding assay and DNA sequencing is under way in this laboratory to determine the cause of its strong activity. The copy number of the Asd ${ }^{+}$plasmids was not different from pBR322 (data not shown).

The asd promoter sequence appears to be located on the $0.20 \mathrm{~kb} E c o \mathrm{RI}-P s t \mathrm{I}$ fragment (Fig. 2). Evidence for this came from two derivative plasmids, both $\mathrm{Asd}^{-}$, which have part of the original HindIII asd gene fragment deleted. One, lacking the $0.6 \mathrm{~kb} \mathrm{BamHI-HindIII}$ fragment downstream of the promoter, made a novel fused protein of only 32000 daltons: presumably aspartate- $\beta$-semialdehyde dehydrogenase which lacks part of the $\mathrm{C}$-terminal end. The other, lacking the $0.2 \mathrm{~kb}$ EcoRI-PstI fragment, produced no detectable $S$. mutans protein. Preliminary sequencing data also support this promoter location: (G. Cardineau, unpublished).

Sutcliffe (1978) reported that cloning foreign DNA into the pBR322 HindIII restriction site does not always change the plasmid's phenotype to $\mathrm{Tc}^{\mathrm{s}}$. The $S$. mutans UAB62 asd gene inserted in one of the two possible orientations (pYA574, pYA575) also maintained the Tcr phenotype. pBR322 DNA has an excellent promoter sequence near the HindIII recognition site (Sutcliffe, 1978): the AT-rich RNA polymerase binding site (Pribnow-box) is located downstream from the HindIII cleavage site, but the 'minus 35' region necessary as the RNA polymerase recognition site is located upstream from the HindIII cleavage site. Expression of $\mathrm{Tc}^{r}$ by one orientation of the asd insert DNA may be due to substitution for only the 'minus 35 ' region, or alternatively, cloned $S$. mutans DNA may provide a complete promoter upstream of the HindIII site. In the latter alternative, there would have to be a second promoter in addition to the asd promoter, since deletion of the asd promoter (pYA576) did not affect tetracycline resistance. Tetracycline minimal inhibitory concentration data for pBR322 and pYA575 plasmid-carrying $\chi 1849$ cells did not help us choose between these two hypotheses. 
We thank our colleagues in the Curtiss laboratory for helpful scientific discussion and technical advice, and Jeffrey Hansen, Pat Pierce, Denise Shaw and Brenda Gosnell for help in preparation of the manuscript. Guy Cardineau was especially helpful with some mapping experiments.

This work was supported by a grant from the National Institute of Dental Research (DE-02670), National Institutes of Health, U.S.A.

\section{REFERENCES}

BACHMANN, B. J. \& Low, K. B. (1980). Linkage map of Escherichia coli K-12. Edition 6. Microbiological Reviews 44, 1-56.

BehNKe, D. \& FerretTI, J. J. (1980). Molecular cloning of an erythromycin resistance determinant in streptococci. Journal of Bacteriology 144, 806-813.

BirnBoIM, H. C. \& Doly, J. (1979). A rapid alkaline extraction procedure for screening recombinant plasmid DNA. Nucleic Acids Research 7, 15131523.

Bolivar, F., Rodriguez, R. L., Betlach, M. C. \& BOYER, H. W. (1977). Construction and characterization of new cloning vehicles. I. Ampicillinresistant derivatives of the plasmid pMB9. Gene 2 , 75-93.

Chang, A. C. Y. \& Cohen, S. N. (1978). Construction and characterization of amplifiable multicopy DNA cloning vehicles derived from P15A cryptic miniplasmid. Journal of Bacteriology 134, 11411156.

Collins, J. (1979). Escherichia coli plasmids packageable in vitro in $\lambda$ bacteriophage particles. Methods in Enzymology 68, 309-326.

Coykendall, A. L. (1974). Four types of Streptococcus mutans based on their genetic, antigenic and biochemical characteristics. Journal of General Microbiology 83, 327-338.

Coykendall, A. L. (1977). Proposal to elevate the subspecies of Streptococcus mutans to species status, based on the molecular composition. International Journal of Systematic Bacteriology 27, 26-30.

CuRTIss, R. III (1965). Chromosomal aberrations associated with mutations to bacteriophage resistance in Escherichia coli. Journal of Bacteriology 89, 28-40.

Curtiss, R. III, JAGUSZTYN-KRYNICKA, E. K., Hansen, J. B., Smorawinska, M., Abiko, Y. \& Cardineau, G. (1982). Expression of Streptococcus mutans plasmid and chromosomal genes in Escherichia coli K-12. In Microbial Drug Resistance, vol. 3, pp. 15-27. Edited by S. Mitsuhashi. Tokyo: Japan Scientific Societies Press. Baltimore: University Park Press.

Frazer, A. C. \& Curtiss, R. III. (1975). Production, properties and utility of bacterial minicells. Current Topics in Microbiology and Immunology 69, 3-84.

GibBons, R. J. \& vanHoute, J. (1975). Dental caries. Annual Review of Medicine 26, 121-136.

Guerry, P., LeBlanc, D. J. \& Falkow, S. (1973). General method for the isolation of plasmid deoxyribonucleic acid. Journal of Bacteriology 116, 1064-1066.

Hamada, S. \& Slade, H. D. (1980). Biology, immunology and cariogenicity of Streptococcus mutans. Microbiological Reviews 44, 331-384.

Hansen, J. B., Abiko, Y. \& Curtiss, R. III (1981). Characterization of the Streptococcus mutans plasmid pVA318 cloned into Escherichia coli. Infection and Immunity 31, 1034-1043.

HaYward, G. S. \& SMITH, M. G. (1972). The chromosome of bacteriophage T5. I. Analysis of the single-stranded DNA fragments by agarose gel electrophoresis. Journal of Molecular Biology 63, 383-395.

Hegeman, G. D., Cohen, G. R. \& Morgan, R. (1970). Aspartic semialdehyde dehydrogenase. Methods in Enzymology 17A, 708-713.

Holland, M. J. \& Westhead, E. W. (1973). Purification and characterization of asparticsemialdehyde dehydrogenase from yeast and purification of an isozyme of glyceraldehyde-3phosphate dehydrogenase. Biochemistry 12, 22642270.

Katz, L., Kingsbury, D. T. \& Helinski, D. R. (1973). Stimulation by cyclic adenosine monophosphate of plasmid deoxyribonucleic acid replication and catabolic repression of the plasmid deoxyribonucleic acid-protein relaxation complex. Journal of Bacteriology 114, 577-591.

LAEMMLI, U. K. \& FAVRE, M. (1973). Maturation of the head of bacteriophage T4. Journal of Molecular Biology 80, 575-599.

LeBlanc, D. J., Hawley, R. J., Lee, L. N. \& St. MARTIN, E. J. (1978). Conjugal transfer of plasmid DNA among oral streptococci. Proceedings of the National Academy of Sciences of the United States of America 75, 3484-3487.

LENNOX, E. S. (1955). Transduction of linked genetic characters of the host by bacteriophage P1. Virology 1, 190-206.

LEVY, S. B. (1975). Very stable prokaryotic messenger RNA in chromosomeless Escherichia coli minicells. Proceedings of the National Academy of Sciences of the United States of America 72, 2900-2904.

Loesche, W. J., Rowan, J., Straffon, L. H. \& Loos, P. J. (1975). Association of Streptococcus mutans with human dental decay. Infection and Immunity 11, 1252-1260.

Macrina, F. L., Reider, J. L., VIRGILI, S. S. \& Kopecko, D. J. (1977). Survey of the extrachromosomal gene pool of Streptococcus mutans. Infection and Immunity 17, 215-226.

Macrina, F. L., Kopecko, D. J., Jones, K. R., Ayers, D. J. \& McCowen, S. M. (1978). A multiple plasmid-containing Escherichia coli strain: convenient source of size reference plasmid molecules. Plasmid 1, 417-420.

Macrina, F. L., Jones, K. R. \& Wood, P. H. (1980). Chimeric streptococcal plasmids and their use as molecular cloning vehicles in Streptococcus sanguis (Challis). Journal of Bacteriology 143, 1425-1435.

Perry, D. \& Kuramitsu, H. K. (1981). Genetic transformation of Streptococcus mutans. Infection and Immunity 32, 1295-1297. 
Rigby, P. W. J., Dieckmann, M., Rhodes, C. \& BERG, P. (1977). Labeling deoxyribonucleic acid to high specific activity in vitro by nick translation with DNA polymerase I. Journal of Molecular Biology 113, 237-251.

SoUTHERN, E. M. (1975). Detection of specific sequences among DNA fragments separated by gel electrophoresis. Journal of Molecular Biology 98, 503-517.

StüBER, D. \& BUJARD, H. (1981). Organization of transcriptional signals in plasmids pBR322 and pACYC184. Proceedings of the National Academy of Sciences of the United States of America 78, 167-171.

SutclifFe, J. G. (1978). The complete nucleotide sequence of the Escherichia coli plasmid pBR322. Cold Spring Harbor Symposia on Quantitative Biology 43, 77-90.

TAIT, R. C. \& BOYER, H. W. (1978). On the nature of tetracycline resistance controlled by the plasmid pSC101. Cell 13, 73-81.

UMBARGER, H. E. (1978). Amino acid biosynthesis and its regulation. Annual Review of Biochemistry 47, 533-606.

Yokogawa, K., Kawata, S., Nishimura, S., Ikeda, Y. \& YoshimuRA, Y. (1974). Mutanolysin, bacteriolytic agent for cariogenic streptococci: partial purification and properties. Antimicrobial Agents and Chemotherapy 6, 156-165. 